\title{
Major Stumbling Block in Brand Portability in Telecom Sector in Coimbatore
}

\author{
T. Shenbhagavadivu, I. Joseline Steffi
}

\begin{abstract}
The researchers are proposing a study is that it will examine the different factors which lead consumers to brand switching, determine the brand loyalty of consumers with preferred telecommunication networks. The study follows the quantitative process. A survey is prepared for data collection and for statistically testing the proposed model. The results of this study support the hypothesis that there is a positive relationship between the age of the respondents has the significant relationship with switched from any other provider or planning to switch. Results suggest that respondents changed their service provider one time, influenced by them to switch current service provider, satisfied with the promotional offers given by the service provider, and finally the brand portability is useful to them. This study will help the telecommunication networks to indentify the priority and preference of their customers
\end{abstract}

Keywords - Brand Portability, Service provider, Satisfaction Level, Consumer, Telecommunication.

\section{INTRODUCTION}

The emergence of the National Telecom Policy in 1994 and 1999 makes the Indian Telecom market to have rapid growth, which marked as third - larger market than China \& South Korea, with projected mobile users of more than one billion. Bharat Sanchar Nigan Limited (BSNL), created by Corporation of India telecommunication service was the India's first operators which provide telephone service throughout the country. After the Introduction of LPG policy (liberalization, privatization, globalization) witnessed Telecom Sector tremendous development, made the communication services easily available to the common man in India. This is an era where numerous private telecom providers are allowed into the Indian market and the telecom industry had become more competitive in nature. The telecom players, both private and public reforms the telecom industry with more advancement in technology, end number of features to the mobile, the cost is reduced, the usage of internet is increased, and makes our country as a "Digital India" as a whole.

The development in telecommunication sectors in India with fast increase in mobile subscriber as a base of network and quality of service for selecting the operators and also emphasis on implementing MNP (Mobile Number Portability). The concept of mobile number portability is changing the mobile operator without changing the number. Number portability is systems that permit a subscriber to keep a "unique" telephone number by changing the mobile operators.

Revised Manuscript Received on September 14, 2019.

Dr. T. Shenbhagavadivu , Assistant Professor, Department of M.Com (IB) \& B. Com (CS), Sri Krishna Arts and Science College, Coimbatore 641008, Tamil Nadu, India. (E-mail: joselinesteffii@skasc.ac.in)

I. Joseline Steffi, Assistant Professor, Department of M.Com (IB) \& B Com (CS), Sri Krishna Arts and Science College, Coimbatore 641008, Tamil Nadu, India.
After a long struggle, India launches the Mobile Number Portability (MNP) in January 2011. It allows the mobile subscribers to hold the existing number by changing the mobile operators. Mobile Service providers are necessitated to increase or improve their service quality in order to avoid the loss of subscribers.

Imposed by the National Regulatory Authority and agreed upon among different network operators, number portability is one of three important mechanisms to enhance fair competition among telecommunication operators and to improve customer service quality. Three types of number portability have been discussed: location portability, service portability, and opera-tor portability. With location portability, a subscriber may change from one location to another without changing his/her telephone number. With service portability, a subscriber may keep the same telephone number when changing telecommunication services. Operator portability refers to the subscriber change the existing services to another service while they retain the same telephone number. Eg.Changing from plain old telephone services (POTs) to integrated service.

\section{REVIEW OF LITERATURE}

Reichheld (1996) identified that customer retention is more important than capturing the new customers.

Lee, Lee \& Feick (2001) stated to sustain in the competitive business environment it is essential to protect and retain the existing customers than focusing on new customers.

Debnath and Shankar (2008) identified that the benchmarking of the mobile service providers based on their performance, the efficiency and quality of service makes the existing customers to retain with the existing operators. The benchmarking is the base to create loyalty among the existing customers. They identified the different parameters for benchmarking of the mobile service providers in India.

Bhatt (2008) studied the students perception on the usage, necessity and amount spend on mobile phones. He also studied the relationship between perspective of students towards different mobile handset companies and mobile service providers.

Aravind Sahay and Nivedita Sharma (2010) researched the sources of the influence on switching behaviour of the subscribers, and found family has a most influencing on the subscribers. Also, they revealed that the customers compare prices irrespective of brand relationships. 
Khan et al.. (2010) have identified the reason of mobile users shifting from existing to others for the best tariffs, services or plan, getting better performance.

Gumucio et al., (2012) have noted that quality on network service, affordable price, behaviour of customer care, outstanding value - added services are the important factors for switching the customers from one service to another. The swapping among customers from one service to another will lead to dissatisfaction.

Rajesh (2013) studied that the people opt for Mobile Number Portability (MNP) is due to dissatisfaction with the poor connectivity and problem in network. And also suggested to the current operators to have innovation in services, improve quality in voice calls and provide better network connectivity.

Murugandam (2013) revealed that Mobile Number Portability (MNP) is for betterment to existing customers as it is easy to change from one operator to another operators.

Chadha, Suresh K and Bhandari, Namitha (2014) stated that the various factors for discontinuing the existing mobile services operators are networks, tariffs, technology, advertisements and rewards respectively.

Kaur, Gurjeet and Sambyal, Ritika (2016) have identified that the switching intention of the customers are influenced by quality in service, relational quality, attractive tariffs, brand reputation, behaviours towards switching and quality in networks.

T. Shenbhagavadivu (2016) researched a model to investigate the influence of various factors in changing and shaping user perception and level of usage of various mobile social networking apps on their Smartphone and also the mobile network portability(MNP)

Aslam, Wajeeha and Frooghi, Reema (2018) in their research on switching behavior among the young adults identified that there is a negative and insignificant impact on switching behavior towards the price and failure of core services. And also found that there is a significant impact on switching behavior towards inconveniences and service encounter failure. The main causes of switching the network among the young adults are better technology.

These researchers provide an opportunity for many upcoming researchers to pursue their study on the mobile network portability (MNP) and other related areas in future.

\section{STATEMENT OF THE PROBLEM}

Several factors such as network quality, service quality, features, prices, offers, brand image, etc., influence the customer to switch from one network service provider to another. The prediction of customer choices depends upon the level of these factors influencing in switching behaviour and exists of relationship among the factors, which in turn brings the changes in the telecommunication industry in greater extent. The major problem in predicting the customer choices exists in the fact that brand switching decisions of the customers are merely done in the basis of several different criteria simultaneously which include factors like brand image, features, network quality, prices, etc. Thus the persistent switching behaviour of customer are urged to review such factors that affect the telecommunication industry. Thus the issue has been more severe in telecommunication industry where the customer get attracted towards competitor offers and features and analyses the expectations of the customers regarding the telecommunication industry service.

There are several major players of the telecommunication industry and those are airtel, Vodafone , Idea, Reliance and Reliance Jio, Tata Docomo and BSNL had the scope of this study is limited to these seven major players of the telecommunication industry. The main purpose of the study is to examine the underlying factors that led to the customer switching behaviour.

\section{OBJECTIVES OF THE STUDY}

- To see through the relationship between brand switching behaviour and the offers of telecommunication operators.

- To analyse the underlying factors that led to the customer switching behaviour.

- To interpret the level of customer satisfaction of various telecommunication service providers

\section{RESEARCH METHODOLOGY}

A convenience sample consisting of 104 respondents participated in the study. Questionnaires were administered to trace out the level of satisfaction attributes which in their judgment plays a very critical role in brand switching behavior. Descriptive analysis, Chisquare analysis was employed to analyse the data. This information was represented in the form of tables and charts with suitable interpretation.

\section{HYPOTHESIS TESTING}

Hypothesis testing is done to find out the number of customers who port in and out for any particular network. It is also used to find out if all the network providers get the equal number of porting requests or not.

\section{ANALYSIS \& INTERPRETATION}

Table No: 1 - Descriptive Statistics

\begin{tabular}{|c|c|c|c|}
\hline Category & Group & $\begin{array}{l}\text { No. of } \\
\text { Respo } \\
\text { ndent }\end{array}$ & $\begin{array}{l}\text { Percen } \\
\text { tage }\end{array}$ \\
\hline \multirow{2}{*}{ Gender } & Male & 45 & 40.9 \\
\hline & Female & 65 & 59.1 \\
\hline \multirow{2}{*}{ Marital Status } & Single & 82 & 78.8 \\
\hline & Married & 22 & 21.2 \\
\hline \multirow{5}{*}{ Age } & $\begin{array}{l}\text { Less than } 20 \\
\text { Years }\end{array}$ & 41 & 39.4 \\
\hline & 21-30 Years & 50 & 48.1 \\
\hline & 31-40 Years & 8 & 7.7 \\
\hline & $41-50$ Years & 5 & 4.8 \\
\hline & Above 50 Years & 0 & 0.0 \\
\hline \multirow{4}{*}{$\begin{array}{l}\text { Educational } \\
\text { Qualification }\end{array}$} & Below $12^{\text {th }}$ & 13 & 12.5 \\
\hline & Under graduate & 8 & 7.7 \\
\hline & Post graduate & 12 & 11.5 \\
\hline & Technical & 71 & 68.3 \\
\hline Current & Airtel & 39 & 37.5 \\
\hline
\end{tabular}




\begin{tabular}{|l|l|l|l|}
\hline \multirow{4}{*}{ Category } & Group & $\begin{array}{l}\text { No. of } \\
\text { Respo } \\
\text { ndent }\end{array}$ & $\begin{array}{l}\text { Percen } \\
\text { tage }\end{array}$ \\
\hline \multirow{4}{*}{$\begin{array}{l}\text { Service } \\
\text { Operator }\end{array}$} & Vodafone & 10 & 9.6 \\
\cline { 2 - 4 } & Idea and & 33 & 7.7 \\
\cline { 2 - 4 } & $\begin{array}{l}\text { Reliance } \\
\text { JIO }\end{array}$ & 31.7 \\
\cline { 2 - 4 } & Tata Docomo & 3 & 2.9 \\
\cline { 2 - 4 } & Aircel & 3 & 2.9 \\
\cline { 2 - 4 } Preference of & BSNL & 8 & 7.7 \\
\hline \multirow{4}{*}{ Switching } & Very unlikely & 17 & 16.3 \\
\cline { 2 - 4 } & Unlikely & 19 & 18.3 \\
\cline { 2 - 4 } & Neutral & 54 & 51.9 \\
\cline { 2 - 4 } & Likely & 8 & 7.7 \\
\cline { 2 - 4 } & Very likely & 6 & 5.8 \\
\hline
\end{tabular}

The set of questions contained in this section is applicable only for those respondents who wish to switch from their current service provider (46 out of 104).

\begin{tabular}{|c|c|c|c|}
\hline Category & Group & $\begin{array}{l}\text { No of } \\
\text { respon } \\
\text { dents }\end{array}$ & $\begin{array}{l}\text { Percent } \\
\text { age }\end{array}$ \\
\hline \multirow{7}{*}{$\begin{array}{l}\text { Service } \\
\text { Provider } \\
\text { they switch } \\
\text { from }\end{array}$} & Airtel & 18 & 39.1 \\
\hline & Vodafone & 4 & 8.7 \\
\hline & Idea & 8 & 17.4 \\
\hline & $\begin{array}{l}\text { Reliance and } \\
\text { JIO }\end{array}$ & 8 & 17.4 \\
\hline & Tata Docomo & 4 & 8.7 \\
\hline & Aircel & 4 & 8.7 \\
\hline & BSNL & 0 & 0.0 \\
\hline \multirow{7}{*}{$\begin{array}{l}\text { Service } \\
\text { provider } \\
\text { they switch } \\
\text { to }\end{array}$} & Airtel & 14 & 30.5 \\
\hline & Vodafone & 4 & 8.7 \\
\hline & Idea & 6 & 13.1 \\
\hline & $\begin{array}{l}\text { Reliance and } \\
\text { JIO }\end{array}$ & 21 & 45.7 \\
\hline & Tata Docomo & 1 & 2.2 \\
\hline & Aircel & 0 & 0.0 \\
\hline & BSNL & 0 & 0.0 \\
\hline \multirow{5}{*}{$\begin{array}{l}\text { Extent of } \\
\text { changing the } \\
\text { service } \\
\text { provider }\end{array}$} & Once & 26 & 56.6 \\
\hline & Twice & 16 & 34.8 \\
\hline & Thrice & 2 & 4.4 \\
\hline & $\begin{array}{l}\text { More than } \\
\text { thrice }\end{array}$ & 2 & 4.4 \\
\hline & Frequently & 0 & 0.0 \\
\hline \multirow{4}{*}{$\begin{array}{l}\text { Major } \\
\text { influence for } \\
\text { switching } \\
\text { decision }\end{array}$} & Self & 17 & 36.95 \\
\hline & Family & 11 & 23.91 \\
\hline & $\begin{array}{l}\text { Unsatisfied } \\
\text { Service } \\
\text { Provider } \\
\end{array}$ & 10 & 21.74 \\
\hline & Brand Image & 8 & 17.4 \\
\hline
\end{tabular}

\section{factors}

\begin{tabular}{|c|c|c|c|}
\hline Factors & Opinion & $\begin{array}{l}\text { No of } \\
\text { Respond } \\
\text { ents } \\
\end{array}$ & $\begin{array}{l}\text { Perce } \\
\text { ntage }\end{array}$ \\
\hline \multirow{6}{*}{$\begin{array}{l}\text { Promotional } \\
\text { Offers }\end{array}$} & Satisfied & 15 & 32.7 \\
\hline & $\begin{array}{l}\text { Highly } \\
\text { satisfied }\end{array}$ & 11 & 23.9 \\
\hline & Neutral & 13 & 28.3 \\
\hline & Unsatisfied & 3 & 6.5 \\
\hline & $\begin{array}{l}\text { Highly } \\
\text { unsatisfied }\end{array}$ & 4 & 8.7 \\
\hline & Total & 46 & 100 \\
\hline \multirow{4}{*}{$\begin{array}{l}\text { Brand } \\
\text { Portability and } \\
\text { its usefulness } \\
\text { for customers }\end{array}$} & Agree & 28 & 60.8 \\
\hline & Neutral & 11 & 23.9 \\
\hline & Disagree & 7 & 15.3 \\
\hline & Total & 46 & 100 \\
\hline
\end{tabular}

Chi - Square Analysis:

\begin{tabular}{|c|c|c|c|c|c|}
\hline S. No & Factors & $\begin{array}{l}\text { Chi } \\
\text { Square } \\
\text { Value }\end{array}$ & $\begin{array}{l}\text { Degre } \\
\text { e } \\
\text { Of } \\
\text { Freed } \\
\text { om }\end{array}$ & $\begin{array}{l}\text { Table } \\
\text { Value }\end{array}$ & Result \\
\hline 1. & $\begin{array}{l}\text { Field and } \\
\text { Extent of } \\
\text { their } \\
\text { switching } \\
\text { behavior. }\end{array}$ & $\begin{array}{l}19.86131 \\
7\end{array}$ & 12 & 21.3 & $\begin{array}{l}\text { No } \\
\text { Signific } \\
\text { ant }\end{array}$ \\
\hline 2. & $\begin{array}{l}\text { Education } \\
\text { al } \\
\text { qualificati } \\
\text { on and } \\
\text { Level of } \\
\text { satisfactio } \\
\text { n. }\end{array}$ & 11.43407 & 12 & 21.3 & $\begin{array}{l}\text { No } \\
\text { signific } \\
\text { ance }\end{array}$ \\
\hline 3. & $\begin{array}{l}\text { Age of } \\
\text { the } \\
\text { responden } \\
\text { ts and } \\
\text { Switched } \\
\text { from any } \\
\text { other } \\
\text { providers } \\
\text { or } \\
\text { planning } \\
\text { to switch. }\end{array}$ & 10.093 & 4 & 9.49 & $\begin{array}{l}\text { Signific } \\
\text { ant }\end{array}$ \\
\hline
\end{tabular}

Promotional offers provided by the service providers have a large impact on the brand portability. So through attractive promotional offers service providers can easily attract the customers towards their network.

The companies should upgrade their network quality and coverage because in cellular networking industry the consumer's core concern is towards the quality. Therefore, in order to value the money spent by customer the companies need to provide quality services. In this way, regardless of high prices the consumer will stay loyal towards the network. 


\section{CONCLUSION}

Conclusively, the study explains the important attributes that play an important and crucial role in influencing the brand switching behavior of consumers in mobile telecommunication sector. The empirical result of the study finds that the tariff packages, internet facilities and promotional activities significantly influenced on brand switching behavior of consumers'. If any company wants to dominate the market and retain their consumers, they must have to consider the switching behavior of consumers. They should introduce such an offer or package as the consumer demands, improve network quality, provide fast internet connectivity, arrange innovative advertising and promotional campaign, and ensure satisfactory customer services; otherwise it will not be possible to survive in the competitive market of mobile telecommunication.

The most important tool to retain customers and prevent their switching behavior includes the customer relationship management. The companies should manage their relationship with customers by updating them via email or sums, assisting them in the best possible manner and by showing empathy towards them.

\section{REFERENCES}

1. Arvind Sahay \&Nivedita Sharma, (2010) Brand relationships and switching behaviour for highly used products in young consumer, Vikalpa, 35(1), 15-30.

2. Aslam, Wajeeha and Frooghi, Reema, (2018) Switching Behaviour of Young Adults in Cellular Service Industry: An Empirical Study of Pakistan, Global Business Review, 19(3), 635-649.

3. Chadha,Suresh K and Bhandari, Namita, (2014) Determinants of Customer Switching towards Mobile Number Portability, Paradigm 18(2), 199-219.

4. Debnath, R.M. and Shankar, R. (2008), "Benchmarking telecommunication service in India: An application of data envelopment analysis", Benchmarking: An International Journal, 15(5), pp.584 - 598.

5. Gumucio, L. M., Pechua'n, I. G., \& Marque's, D. P.,( 2012) An exploratory study of the determinants of switching and loyalty in prepaid cell phone users: An application of concept mapping. Service Business, 7(4), 603-622.

6. Kaur, Gurjeet and Sambyal, Ritika,( 2016) VIKALPA The Journal for Decision Makers, 41(1), 74-95.

7. Khan, A. A., Jamwal, S., \&Sepehri, (2010) M. M., Applying data mining to customer churn prediction in an internet service provider. International Journal of Computer Applications, 9(7), 8-14.

8. Reichheld, F. F.,(1996) Learning from customer defections. Harvard Business Review, 74(2), 56-69.

9. T. Shenbhagavadivu, (2016) Factors influencing perception of mobile social networking apps among undergraduate level students, Intercontinental Journal of Human Resource Research Review, Volume 4, Issue 6, pp: 91 - 95. 